\title{
FROM SEPARATE ACCOUNTING TO FORMULA APPORTIONMENT: ANALYSIS IN A DYNAMIC FRAMEWORK
}

\author{
DOINA MARIA RADULESCU
}

CESIFO WORKING PAPER NO. 2122

CATEgORY 1: PUBLIC FINANCE

OCTOBER 2007

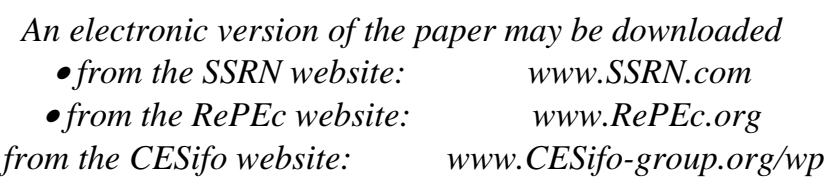




\title{
FROM SEPARATE ACCOUNTING TO FORMULA APPORTIONMENT: ANALYSIS IN A DYNAMIC FRAMEWORK
}

\begin{abstract}
This paper analyzes the switch from Separate Accounting to Formula Apportionment in a dynamic framework. The model features both purely domestic corporations and a domestic multinational which invests at home and abroad as well as a purely foreign corporation and a foreign multinational which invests in the foreign economy as well as in the domestic country. Using such a framework we can show that since the new FA rules apply only to multinational firms, this will affect the domestic activity of purely domestic or foreign corporations since these stick to SA and thus the marginal product of labour and capital will be different for the two firm types. This in turn will affect the investment incentives and distort capital and labour allocation between the different types of enterprises operating in an economy.
\end{abstract}

JEL Code: D92, F23, E62, H25.

Keywords: capital income taxation, separate accounting, formula apportionment, dynamic optimization, multinational firms.

\author{
Doina Maria Radulescu \\ Center for Economic Studies and CESifo \\ at the University of Munich \\ Schackstr. 4 \\ 80539 Munich \\ Germany \\ radulescu@lmu.de
}

September 2007 


\section{Introduction}

For almost 50 years now, European policymakers have debated on the stance of corporate taxation in Europe especially on the issue whether to harmonize or not corporate tax systems in the European Union. Most proposals in this direction which focussed on the coordination of tax rates were however rather unsuccesfull due to the reluctance of Member Countries to give up their sovereignty of setting these kind of tax rates. Nevertheless, a specific proposal has found more supporters. It is the proposal of introducing a common consolidated tax base accompanied by a so-called formula apportionment (European Commission 2001). This idea was first advanced in 2001 in the Commission's report "Company Taxation in the Internal Market" and has been the working focus of a 2004 established Common Consolidated Corporate Tax Base Working Group. According to this proposal, the corporate income of a multinational corporation (MNC) is consolidated and allocated to the different jurisdictions according to a specific formula. This formula measures the relative activity of the $\mathrm{MNC}$ in the different regions by using different measures such as relative sales, payroll or the relative capital stock employed in that country. Since the individual country still has the power to set the corporate tax rate and thus does not have to give up so much sovereignity, this proposal seems to be a preferred alternative compared to the idea of harmonizing tax rates.

The idea behind all these proposals was the creation of a level playing field for the taxation of MNCs in Europe. In the light of increased tax competition national governments find it increasingly difficult to tax the income of these corporations since these have the possibility to shift profits to low-tax countries. These profit shifting activities are incurred via the use of transfer pricing, thin capitalization rules, or loss shifting activities. Taxation based on Separate Accounting (SA) is particularly prone to these type of activities and empirical evidence shows that indeed MNCs try to shift profits from high-tax to low-tax countries via these channels (see Hines 1999, BÜtTnER AND RUF 2007). Under the presently applied system of SA, the profits of a MNC are assigned to the state where they are earned. Then, the individual country levies its national tax rate on the profits of MNCs located in its jurisdictions. Thus, it is no wonder that MNCs would try to use 
different techniques to increase their tax base in low-tax jurisdictions. Moreover, under SA governments have an incentive to reduce their tax rates to become attractive as an investment location. Therefore, countries engage in a so-called race to the bottom and do not take into account the effects which their own low national tax rate triggers on other countries. (Mintz, 1999)

Whereas SA is the usual taxation method in most European countries, a diffeent tax system namely Formula Apportionment (FA) applies in the US and Canada. ${ }^{1}$

The literature on FA vs. SA actually started 1980 with MCLuRE's (1980) famous contribution. He was the first to show that FA basically transforms the corporate income tax into three different taxes on the factors payroll, sales and capital stock used in the formula. Thus, by modifying the weights used for these activity measures in the formula, governments can stimulate investment and employment within their own jurisdictions (see also Goolsbee And Maydew 2000). Further papers which deal with the aspects of FA and tax competition are Gordon And Wilson (1986), Anand And Sansing (2000), Gérard And Weiner (2003), Eggert And Schjelderup (2003,2005), Nielsen et. al (2004) and Sørensen (2004) to name just a few. While Gordon And Wilson (1986) show that in equilibrium nations will choose to apply inefficiently low tax rates, NIELSEN ET AL (2004) and SørEnsen (2004) find mixed effects on welfare if countries choose to witch from SA to FA. Further studies on the effects of FA include WeInER (1999), Mintz (1999), Mintz and Smart (2004), Nielsen et al. (2003). Apart from the above mentioned theoretical papers there exist also a number of empirical studies which deal wih the effects of introducing FA, of which one should mention for instance FUEST ET. AL (2006) which consider the implications of implementing a common consolidated tax base and FA on the size of the EU wide tax base and on its distribution between EU member countries.

This paper differs from the above mentioned studies in that it is on the hand the first to analyze the effects from the transition from SA to FA in a dynamic setting. On the other hand we also consider the effects of this transition in a setting in which not

\footnotetext{
${ }^{1} \mathrm{~A}$ similar system is also applied in Switzerland and in Germany at local level for the so-called local trade tax ("Gewerbesteuer").
} 
only MNCs but also only purely domestic corporations (and purely foreign corporations) operate, an aspect which has also not been treated in the literature thus far. Since the two types of firms coexist but only MNCs have access to FA, the two different taxation systems will have different effects on the marginal product of capital and labour for the two firm types. Accordingly, under different assumptions, one system or the other may benefit certain types of firms such that for instance investments by MNCs will under certain circumstances crowd out investments and employment by purely domestic firms. One paper that also analyzes the effects of the co-existence of these two distinct taxation systems, looking however only at the effects on MNCs is by RIEDEL AND RUNKEL (2007).

The paper is structured as follows. Section 2 sets up the model of two MNCs which operate both in the domestic and in the foreign economy and two purely domestic corporations, all subject to a system of taxation under SA. In Section 3 we show how introducing FA affects the investment decision and labour demand of the two different firm types and Section 4 concludes.

\section{The Model}

\subsection{Purely Domestic and Foreign Corporations}

The model follows Keuschnigg (2003) and Keuschnigg (2005).

Domestic and foreign production is carried out on the one hand by purely domestic and purely foreign corporate firms, which both rely on a basic neoclassical, linearly homogenous production technology with positive but diminishing marginal rates of return. The price of the uniform, tradeable output good, $Y$, is normalized to one and the factors capital, $K$, labour, $L$ serve as inputs. The superscript $f \in\{H, F\}$ distinguishes the location of the firms, so in the domestic or in the foreign economy.

$$
Y_{t}^{f}=F\left(K_{t}^{f}, L_{t}^{f}\right)=F_{K}^{f} \cdot K^{f}+F_{L}^{f} \cdot L^{f}
$$

Capital expands over time whenever gross investment, $I$, exceeds the depreciation of 
the existing stock of capital, $\delta K^{f}$. The equation of motion for capital thus states:

$$
G K_{t+1}^{f}=I_{t}^{f}+(1-\delta) K_{t}^{f}
$$

The variable $G$ which enters each differential equation in the model denotes the exogenous trend growth in labor productivity, $G=1+g$. Accordingly, in the balanced growth equilibrium all variables grow at the rate $g$.

Investment additionally incurs adjustment costs of $J^{f}$ for each unit of capital installed. The adjustment costs reflect positive but diminishing marginal returns to capital formation and can be interpreted as the costs which arise due to a firm's internal reorganization. The adjustment cost function is linearly homogenous in investment and capital and convex in investments:

$$
\begin{aligned}
& J^{f}=J\left(I^{f}, K^{f}\right)=I^{f} \cdot J_{I}^{f}+K^{f} \cdot J_{K}^{f}, \\
& \text { with } \quad J_{I}>0 ; \quad J_{I I}>0 ; \quad J_{I I}<0 \text {. }
\end{aligned}
$$

The steady state adjustment costs are zero and do not influence the steady state solution.

We follow the "New View" of dividend taxation. Accordingly, distributed dividends $D^{f}$ are determined residually as the difference between net-of-tax profits and investment outlays. Profits are given by output $Y^{f}$ less adjustment costs and wage payments $w^{f} L^{f}$. $\tau^{f}$ denotes the corporate tax in the respective country and $e^{f}$ stands for a tax allowance granted for new investments. If $e^{f}=1$ we have the case of immediate write-off.

$$
D^{f}=\left(1-\tau^{f}\right)\left(Y^{f}-J^{f}-w^{f} L^{f}\right)-\left(1-e^{f} \tau^{f}\right) I^{f},
$$

The required return before taxes $r^{V, f}$ has to clear the market for domestic/foreign equity.

The representative agent is indifferent between investing his or her money in the capital market or in real assets, since the net of tax return on both investment alternatives has 
to adjust due to arbitrage. Thus, the no-arbitrage condition states:

$$
r_{t}^{V, f} V_{t}^{f}=\left(1-t^{D, f}\right) D_{t}^{f}+\left(1-t^{G, f}\right)\left(G V_{t+1}^{f}-V_{t}^{f}\right)
$$

Accordingly, in equilibrium, the net return on firm equity has to equal the net of tax dividend payment and the net of tax capital gains which can be derived from holding firm shares.

Rearranging the no arbitrage condition given in (2.5), the differential equation determining the domestic and foreign firm value becomes:

$$
R_{t}^{V, f} V_{t}^{f}=\frac{1-t^{D, f}}{1-t^{G, f}} D_{t}^{f}+G V_{t+1}^{f}, \quad R_{t}^{V, f} \equiv 1+r_{t}^{V, f} /\left(1-t^{G, f}\right)
$$

Solving forward equation (2.6) the firm value of purely domestic or purely foreign corporate firms at any period $t$ can be assessed by:

$$
V_{t}^{f}=\sum_{S=t}^{\infty} \frac{\frac{1-t^{D, f}}{1-t^{G, f}} D_{t}^{f}}{1+r_{t}^{V, f} /\left(1-t^{G, f}\right)} \prod_{Z=t}^{S+1} \frac{1+g}{1+r_{t}^{V, f} /\left(1-t^{G, f}\right)}
$$

Accordingly, the firm value is given by the discounted sum of all future tax adjusted net distributions, $\frac{1-t^{D, f}}{1-t^{G, f}} D_{t}^{f}$, to the firm owners.

Firms' goal is to maximize their value by choosing optimal labor demand and optimal investments from period $t$ onwards. Thereby, the firm value increases with the amount of capital accumulated from the past. Applying a value function of the form $V\left(K_{t}^{f}\right)$ and keeping in mind that a firm can only affect the end of period firm value, $V_{t}^{e, f} \equiv\left(1+r_{t}^{e, f}\right) V_{t}^{f}$, with it's current actions in period $t$, the Bellman equation of dynamic programming states:

$$
V^{e f}\left(K_{t}^{f}\right)=\max _{I^{f}, L^{f}}\left\{\frac{1-t^{D, f}}{1-t^{G, f}} D_{t}^{f}+\frac{G V^{e f}\left(K_{t+1}^{f}\right)}{R_{t+1}^{V f}} \quad \text { s.t. eq. (2.2) }\right\} .
$$

The shadow price of capital, $\eta_{t}^{f}=d V_{t}^{e f} / d K_{t}^{f}$, is defined as the marginal change in the firm value, if one additional marginal unit of capital is accumulated. The solution to the intertemporal maximization problem of the firm is given by the following optimality 
conditions for the control variables labour and investment

$$
\begin{aligned}
L^{f} & : \quad w^{f}=F_{L^{f}} \\
I^{f} & : \quad \frac{\eta_{t+1}^{f}}{R_{t+1}^{V, f}}=\frac{1-t^{D f}}{1-t^{G f}}\left[\left(1-\tau^{f}\right) J_{I}^{f}+\left(1-e^{f} \tau^{f}\right)\right] .
\end{aligned}
$$

The optimal demand for labour is determined by the equality of the marginal product of labor, $F_{L_{i}}^{f}$ and the corresponding labor cost $w^{f}$.

The second optimality condition defines the firm's optimal investment policy: It requires that the present value of the marginal benefit arising through one additional unit of capital tomorrow, $\frac{\eta_{t+1}^{f}}{R_{t+1}^{V, f}}$, is identical with the incurred marginal cost for carrying out this investment. The incurred cost of the marginal investment includes the tax adjusted cost of the investment, $\frac{1-t^{D, f}}{1-t^{G, f}}\left(1-e^{f} \tau^{f}\right)$, as well as adjustment costs of size $\frac{1-t^{D f}}{1-t^{G f}}\left(1-\tau^{f}\right) J_{I}^{f}{ }^{2}$

The envelope conditions concerning the stock variable capital is

$$
K^{f}: \eta^{f}=\frac{1-t^{D, f}}{1-t^{G, f}}\left(1-\tau^{f}\right)\left(F_{K^{f}}-J_{K^{f}}\right)+(1-\delta) \frac{\eta_{t+1}^{f}}{R_{t+1}^{V f}}
$$

The shadow price of capital as given by the firm's envelope condition (2.11) defines the value of an induced marginal profit: Adding one more unit of capital creates a marginal profit stream consisting of two different components: first, profits increase by the marginal product of capital; second, due to lower adjustment costs future revenues increase.

Combining eq.(2.11) and (2.9) we get the following expression for the steady state cost of capital

$$
F_{K}^{f}=\left(\frac{r^{V, f}}{1-t^{G, f}}+\delta\right) \frac{1-e^{f} \tau^{f}}{1-\tau^{f}}
$$

Without taxes, the investment must offer a rate of return at least equal to depreciation costs and interest so $F_{K}^{f}=r^{V, f}+\delta$. The propensity to invest also depends on the tax

\footnotetext{
${ }^{2}$ In a world without taxation - implying zero tax rates- the optimality condition (2.9) simplifies to $\left[1+J_{I}^{f}\right]$ in the phase of transition and to 1 in the steady state, when adjustment costs are zero. Hence, the model arrives at the same standard investment criterion, implying that the shadow price of capital has to equal one, as known from standard investment theory.
} 
allowance for investments, $e^{f}$. This term encompasses both depreciation for tax purposes and direct investment premia, and reduces the actual tax burden if $e^{f}>0$.

Differentiating (2.12) with respect to the tax rate under consideration, we find that reducing the corporate income tax as well as the capital gains rate has a positive impact on investment, because in each case the cost of capital declines:

$$
\begin{aligned}
\frac{d F_{K}^{f}}{d \tau^{f}} & =\left(\frac{r^{V f}}{1-t^{G f}}+\delta\right) \frac{1-e^{f}}{\left(1-\tau^{f}\right)^{2}}>0 \\
\frac{d F_{K}^{f}}{d \tau^{G, f}} & =\frac{r^{V f}\left(1-e^{f} \tau^{f}\right)}{\left(1-\tau^{G, f}\right)^{2}\left(1-\tau^{f}\right)}>0 .
\end{aligned}
$$

The economic implication of an increase in the corporate tax rate is obvious. If the corporate tax rate increases, returns stemming from real investments are more heavily taxed compared to those from a financial investment which is not subject to the corporate tax rate. Hence, the cost of capital increases resulting in less real investments. Concerning an increase in the capital gains tax the cost of capital increases to the extent that profit retentions are used as a marginal source of finance. As a consequence, the investment activity will slow down. Since we assumed the "New View" of dividend taxation to hold, the dividend tax will not influence the cost of capital and thus the investment decision.

\subsection{Home Based Multinationals and Foreign Based Multina- tionals}

In this Section we now turn to the production and investment decision of home based and foreign based multinationals under SA.

Both home and foreign based multinationals also rely on a basic neoclassical, linearly homogenous production technology with positive but diminishing returns to scale. However, besides capital and labour we consider an additional input, namely location specific rents (fixed factors $E^{H H}, E^{H F}$ and $E^{F}, E^{F H}$ for home and foreign based MNCs respectively), which ensure that production takes place both domestically and abroad and we do not have a corner solution. Furthermore, in both cases the parent supplies an input 
$Q^{H}\left(Q^{F}\right)$ to the foreign subsidiary which is used in the subsidiary's production process. This modelling approach helps us depict the possibility of using transfer pricing to shift profits between the parent and the affiliate.

$$
\begin{aligned}
Y^{H H} & =Y\left[F\left(K^{H H}, L^{H H}\right), E^{H}\right], \quad Y^{H F}=Y\left[F\left(K^{H F}, L^{H F}\right), Q^{H}, E^{H F}\right] \\
Y^{F F} & =Y\left[F\left(K^{F F}, L^{F F}\right), E^{F}\right], \quad Y^{F H}=Y\left[F\left(K^{F H}, L^{F H}\right), Q^{F}, E^{F H}\right]
\end{aligned}
$$

$Y^{H H}$ and $Y^{H F}$ denote the production of the home based multinational at home and abroad whereas $Y^{F F}$ and $Y^{F H}$ stand for the output of the foreign based multinational in the foreign and in the domestic economy respectively.

The cost of equity $r^{m}$ is fixed on international capital markets since the marginal investor is not subject to domestic/foreign personal taxes on dividends and capital gains, $t^{D f}$ and $t^{G f}$. These taxes will determine only portfolio investments but not direct investments by multinationals.

Taxation of FDI follows the exemption method. Accordingly, the total effective tax rate for home based multinationals abroad is $\tau^{H F}$, the effective tax wedge $1-\tau^{H F}$ and the domestic tax revenue is 0 per $€$ foreign profit. For foreign based multinationals the effective tax burden on their activities in the domestic economy will be $\tau^{H}$ and the foreign tax revenue per $€$ domestic profit will also be 0 under SA.

As mentioned above we allow for the possibility of profit shifting by MNCs between headquarters and affiliate by the use of transfer pricing for intra-company transactions ${ }^{3}$. The true transfer price $p^{Q H}\left(p^{Q F}\right)$ is normalized to unity. If the company underestimates the transfer price it will shift $p^{Q H}-1 / p^{Q F}-1$ profits from the headquarter to the affiliate and vice versa in case the transfer price is overestimated. However, these transfer pricing activities involve some agency $\operatorname{costs} c^{H}=c\left(p^{Q H}-1\right) /\left(c^{F}=c\left(p^{Q F}-1\right)\right)$ which can be interpreted as the risk of being detected or the effort linked to hiding the true cost of transfer pricing (RIEDel AND Runkel 2007, KeUsChnigg 2005).

The shareholders receive dividends distributed both by the parent $D^{H H}\left(D^{F F}\right)$ and

\footnotetext{
${ }^{3}$ The terms in brackets stand for the foreign based MNC.
} 
by the subsidiary $D^{H F}\left(D^{F H}\right)$ in the case of domestic(foreign) based MNCs respectively. These dividends from worldwide profits, net of source corporation tax less investments equal $^{4}$

$$
\begin{aligned}
& D^{H H}=\left(1-\tau^{H}\right)\left(Y^{H H}-J^{H H}-w L^{H H}+\left(p^{Q H}-1-c^{H i}\right) Q^{H}\right)-\left(1-e^{H} \tau^{H}\right) \frac{I^{H H}}{(2.16)} \\
& D^{H F}=\left(1-\tau^{H F}\right)\left(Y^{H F}-J^{H F}-w^{F} L^{H F}-p^{Q H} Q^{H}\right)-\left(1-e^{F} \tau^{H F}\right) I^{H F} . \\
& D^{F F}=\left(1-\tau^{F}\right)\left(Y^{F F}-J^{F F}-w^{F} L^{F F}+\left(p^{Q F}-1-c^{F}\right) Q^{F}\right)-\left(1-e^{F} \tau^{F}\right) I^{F F} \\
& D^{F H}=(1-17)
\end{aligned}
$$

Here $\tau^{H}$ and $\tau^{H F}$ denote the corporate taxes of the domestic and foreign economy respectively. Therefore, since we apply the source principal and SA the domestic profits of the home based MNC and of the foreign based MNC are subject to the same domestic tax rate such that $\tau^{H}=\tau^{F H}$. Similarly, the foreign corporate tax applies to the foreign profits of home based and foreign based MNCs $\left(\tau^{F}=\tau^{H F}\right)$. Profits of the headquarters are determined as output produced in the respective country $Y^{H H}\left(Y^{F F}\right)$ less adjustment costs $J^{H H}\left(J^{F H}\right)$, wage payments $w L^{H H}\left(w^{F} L^{F F}\right)$ and the income received from the subsidiary for the supplied input less the agency costs of transfer pricing. Similarly, profits of the subsidiary are determined as output produced and sold abroad $Y^{H F}\left(Y^{F H}\right)$ less adjustment costs $J^{H F}\left(J^{F H}\right)$, wage payments to the labour force $L^{H F}\left(L^{H F}\right)$ employed abroad at the wage rate $w^{F}(w)$ prevailing in the respective economy and less the payment to the parent for the supplied input $p^{Q H} Q^{H}\left(p^{Q F} Q^{F}\right)$.

Given that we model the case of small open economies, the firms take the world market interest rate $r^{m}$ as given. Thus the end of period value of the home based MNC is given by

$$
\begin{aligned}
& V^{e H}\left(K_{t}^{H H}, K_{t}^{H F}\right)=\max D^{H H}+D^{H F}+G V_{t+1}^{e H} / R_{t+1}^{m} \quad \text { s.t. }, \\
& G K_{t+1}^{H H}=I_{t}^{H H}+(1-\delta) K_{t}^{H}, \quad G K_{t+1}^{H F}=I_{t}^{H F}+(1-\delta) K_{t}^{H F}
\end{aligned}
$$

and of the foreign based MNC by

\footnotetext{
${ }^{4}$ We again allow for the possibility to deduct part of new investments from the tax base. This is incorpoarted in our parameter $e$
} 


$$
\begin{aligned}
V^{e F}\left(K_{t}^{F}, K^{F H}\right) & =\max D_{t}^{F F}+D_{t}^{F H}+G V_{t+1}^{e F} / R_{t+1}^{m} \quad \text { s.t. } \\
G K_{t+1}^{F} & =I_{t}^{F}+(1-\delta) K_{t}^{F}, \quad G K_{t+1}^{F H}=I_{t}^{F H}+(1-\delta) K_{t}^{F H} .
\end{aligned}
$$

where $R^{m}=1+r^{m}$. Definig by $d V_{t}^{e H} / d K_{t}^{H F} \equiv \eta_{t}^{H F}\left(d V_{t}^{e F} / d K_{t}^{F H} \equiv \eta_{t}^{F H}\right)$ the shadow price of capital employed in the economy where the affiliate operates, we can derive the following optimality conditions for the control variables domestic and foreign labour, investments undertaken at home and abroad as well as for the intra-company supplied input $Q^{H}\left(Q^{F}\right)$ and its price $p^{Q H}\left(p^{Q F}\right)$

The optimality conditions for the home based MNC state
(a) $L^{H H}: d Y^{H H} / d L^{H H}=w$,
(b) $L^{H F} \quad: \quad d Y^{H F} / d L^{H}=w^{F}$,
(c) $I^{H H}: \eta_{t+1}^{H H} / R_{t+1}^{m}=\left(1-\tau^{H}\right) J_{I}^{H H}+1-e \tau^{H}$,
(d) $\quad I^{H F}: \eta_{t+1}^{H F} / R_{t+1}^{m}=\left(1-\tau^{H F}\right) J_{I}^{H F}+1-e^{F} \tau^{H F}$,
(e) $Q^{H}:\left(1-\tau^{H}\right)\left(p^{Q H}-1-c^{H}\right)=\left(1-\tau^{H F}\right)\left(p^{Q H}-Y_{Q}^{H}\right)$,
(f) $\quad p^{Q H} \quad: \quad\left(1-\tau^{H}\right)\left(1-c^{\prime}\right)=\left(1-\tau^{H F}\right) \Rightarrow c^{\prime}=\frac{\tau^{H F}-\tau^{H}}{\left(1-\tau^{H}\right)}$.

Optimality conditions for foreign based MNCs
(a) $\quad L^{F F}: d Y^{F F} / d L^{F F}=w^{F}$,
(b) $L^{F H}: d Y^{F H} / d L^{F H}=w$,
(c) $I^{F F}: \eta_{t+1}^{F F} / R_{t+1}^{m}=\left(1-\tau^{F}\right) J_{I}^{F F}+1-e^{F} \tau^{F}$,
(d) $I^{F H}: \eta_{t+1}^{F H} / R_{t+1}^{m}=\left(1-\tau^{F H}\right) J_{I}^{F H}+1-e \tau^{F H}$,
(e) $Q^{F}:\left(1-\tau^{F}\right)\left(p^{Q F}-1-c^{F}\right)=\left(1-\tau^{F H}\right)\left(p^{Q F}-Y_{Q}^{F H}\right)$,
(f) $\quad p^{Q F} \quad:\left(1-\tau^{F}\right)\left(1-c^{\prime}\right)=\left(1-\tau^{F H}\right)$

The first two conditions in both sets of the above equations determine the level of 
optimal labour demand at home and abroad. In each country firms will employ labour up to the point where the marginal product of labour in the domestic and foreign economy equals the respective wage rate. Equations $(2.20 \mathrm{c}$ and $\mathrm{d})$ and $(2.21 \mathrm{c}$ and $\mathrm{d})$ show the MNCs' optimal investment policy: These conditions require that the present value of the marginal benefit arising through one additional unit of capital employed at home or abroad tomorrow, $\eta_{t+1}^{H} / R_{t+1}^{m}\left(\eta_{t+1}^{F F} / R_{t+1}^{m}\right)$ and $\eta_{t+1}^{H F} / R_{t+1}^{m}\left(\eta_{t+1}^{F H} / R_{t+1}^{m}\right)$ respectively, is identical with the incurred marginal cost for carrying out this investment. The incurred cost of the marginal investment includes the adjustment costs and the tax adjusted cost of the investment, $1-e \tau^{H}$ and $1-e^{F} \tau^{H F}$ in case of the home based MNC and $1-e^{F} \tau^{F}$ and $1-e \tau^{F H}$ in case of the foreign based MNC. Thus one can see that the investment decision crucially depends on the source corporate tax rate prevailing in the two economies while the labour demand is affected by the respective wage rate. The 5th optimality condtion shows the optimal amount of input supplied to the subsidiary. The home (foreign) based MNC will supply inputs to its affiliate as long as the net of tax received payment less concealment costs is larger or equal to the net of tax payment the subsidiary has to pay to the parent. Finally, the last equation shows the optimal transfer price which is determined under SA by the equality between the marginal concealment cost and the marginal gain from profit shifting given by the relative difference between the domestic and the foreign corporate tax rate.

Finally the envelope conditions for the stock variables $K^{H}, K^{H F}, K^{F F}$ and $K^{F H}$ define the value of an induced marginal profit. The profit stream created by one more unit of capital includes the increased marginal product of capital less adjustment costs.

$$
\begin{aligned}
& \eta_{t}^{H H}=\left(1-\tau^{H}\right)\left(Y_{K}^{H H}-J_{K}^{H H}\right)+(1-\delta) \eta_{t+1}^{H H} / R_{t+1}^{m}, \\
& \eta_{t}^{H F}=\left(1-\tau^{H F}\right)\left(Y_{K}^{H F}-J_{K}^{H F}\right)+(1-\delta) \eta_{t+1}^{H F} / R_{t+1}^{m} . \\
& \eta_{t}^{F F}=\left(1-\tau^{F}\right)\left(Y_{K}^{F F}-J_{K}^{F F}\right)+(1-\delta) \eta_{t+1}^{F F} / R_{t+1}^{m}, \\
& \eta_{t}^{F H}=\left(1-\tau^{F H}\right)\left(Y_{K}^{F H}-J_{K}^{F H}\right)+(1-\delta) \eta_{t+1}^{F H} / R_{t+1}^{m} .
\end{aligned}
$$


Once again by combining eq.(2.20c), (2.20d), and the envelope conditions for home based MNCs we can derive the following equations which depict the different investment incentives. ${ }^{5}$

$$
r^{m}=\frac{1-\tau^{H}}{1-e \tau^{H}} Y_{K}^{H H}-\delta=\frac{1-\tau^{F}}{1-e^{F} \tau^{F}} Y_{K}^{H F}-\delta .
$$

Similarly, for foreign based MNCs, from eq.(2.21c), (2.21d) and eq.(2.23) we get

$$
r^{m}=\frac{1-\tau^{F}}{1-e^{F} \tau^{F}} Y_{K}^{F F}-\delta=\frac{1-\tau^{H}}{1-e \tau^{H}} Y_{K}^{F H}-\delta .
$$

Thus, given that the cost of equity is fixed on the world market and given the source taxes on corporate profits prevailing in the domestic and in the foreign economy, the marginal product of capital in the two economies has to adjust accordingly to make an investment at home or abroad attractive. If the two countries allow both for instance for immediate write-off of new investments, such that $e=e^{F}=1$, than the standard result which equates the marginal product of capital to the given interest rate is derived. If on the contrary both countries allow only for true economic depreciation such that $e=$ $e^{F}=0$ the above equations turn to

$$
r^{m}=\left(1-\tau^{H}\right) Y_{K}^{H H}-\delta=\left(1-\tau^{F}\right) Y_{K}^{H F}-\delta=\left(1-\tau^{F}\right) Y_{K}^{F F}-\delta=\left(1-\tau^{H}\right) Y_{K}^{F H}-\delta
$$

This condition shows that the investment incentives crucially depend on the profit tax rates and that MNCs will invest in the two economies up to the point where the net of tax marginal products of capital are equalized.

\section{Introducing Formula Apportionment (FA)}

We now turn to the effects of introducing a new system of taxing the profits of MNCs. Under this approach the profits of both the headquarter and the affiliated company are

\footnotetext{
${ }^{5}$ Given that we assume the SS adjustment costs are zero, i.e. $J=J_{I}=J_{K}=0$
} 
consolidated and then apportioned to the respective countries according to a specific formula. We assume the formula contains capital and payroll as factors, while the share of each factor in the formula is denoted by $\operatorname{sh} K$ and $\operatorname{sh} L$ for the domestic economy and $s f K$ and $s f L$ for the foreign economy. To avoid loss of generality we assume each country has the power to choose apart from the tax rate also the shares of capital and labour in the formula. Due to the consolidated tax base, MNCs do not have any incentives to shift profits by means of transfer pricing. Thus, in the below formulae which show the tax burden of home and foreign based MNCs at home and abroad, the transfer pricing terms drop out (see the terms in brackets $A$ and $C$ respectively).

$$
\begin{aligned}
& T^{H}=\tau^{H} \cdot(\underbrace{\operatorname{sh} K \frac{K^{H}}{K^{H}+K^{H F}}+\operatorname{sh} L \frac{L^{H}}{L^{H}+L^{H F}}}_{B 1}) . \\
& \underbrace{\left(Y^{H}-J^{H}-w L^{H}+Y^{H F}-J^{H F}-w^{F} L^{H F}\right)}_{A} \\
& T^{H F}=\tau^{F} \cdot(\underbrace{s f K \frac{K^{H F}}{K^{H}+K^{H F}}+s f L \frac{L^{H F}}{L^{H}+L^{H F}}}_{B 2}) \\
& \cdot \underbrace{\left(Y^{H}-J^{H}-w L^{H}+Y^{H F}-J^{H F}-w^{F} L^{H F}\right)}_{A} \\
& T^{F}=\tau^{F} \cdot(\underbrace{s f K \frac{K^{F}}{K^{F}+K^{F H}}+s f L \frac{L^{F}}{L^{F H}+L^{F}}}_{D 1}) \\
& \underbrace{\left(Y^{F F}-J^{F F}-w^{F} L^{F F}+Y^{F H}-J^{F H}-w L^{F H}\right)}_{C} \\
& T^{F H}=\tau^{H} \cdot(\underbrace{\operatorname{sh} K \frac{K^{F H}}{K^{F}+K^{F H}}+\operatorname{sh} L \frac{L^{F H}}{L^{F}+L^{F H}}}_{D 2}) \\
& \cdot(\underbrace{Y^{F F}-J^{F F}-w^{F} L^{F F}+Y^{F H}-J^{F H}-w L^{F H}}_{C})
\end{aligned}
$$

Accordingly, under the new taxation system, ${ }^{6}$ distributed dividends will equal profits

\footnotetext{
${ }^{6}$ We assume for simplicity $e=e^{F}=0$
} 
less adjustment costs, wage payments and net investments and the tax liability due in the respective country, so $T^{H}$ and $T^{H F}$ for the profits of the home based MNC at home and abroad and $T^{F}$ and $T^{F H}$ for the profits of the foreign based MNC in the foreign and in the domestic economy.

$$
\begin{aligned}
D^{H H} & =Y^{H H}-J^{H H}-w L^{H H}-I^{H H}-T^{H}, \\
D^{H F} & =Y^{H F}-J^{H F}-w^{F} L^{H F}-I^{H F}-T^{H F} . \\
D^{F F} & =Y^{F F}-J^{F F}-w^{F} L^{F F}-I^{F}-T^{F}, \\
D^{F H} & =Y^{F H}-J^{F H}-w L^{F H}-I^{F H}-T^{F H} .
\end{aligned}
$$

As before, $D^{H H}$ and $D^{H F}$ are the dividends distributed by home based MNC and $D^{F F}$ and $D^{F H}$ denote the dividends of the foreign based MNC. Inserting these new expressions in eq.(2.18) and (2.19) we can derive the following new optimality conditions for labour and capital which apply under FA.

$$
\begin{aligned}
& \left(\frac{d Y^{H H}}{d L^{H H}}-w\right)\left(1-\tau^{H} B 1-\tau^{F} B 2\right) \\
& -A \cdot \frac{L^{H F}}{\left(L^{H}+L^{H F}\right)^{2}}\left(\tau^{H} \cdot s h L-\tau^{F} \cdot s f L\right) \\
\Rightarrow & \frac{d Y^{H H}}{d L^{H H}}=w+\frac{1}{\left(1-\tau^{H} B 1-\tau^{F} B 2\right)} \cdot A \cdot \frac{L^{H F}}{\left(L^{H}+L^{H F}\right)^{2}}\left(\tau^{H} \cdot s h L-\tau^{F} \cdot s f L\right) \\
& \left(\frac{d Y^{H F}}{d L^{H F}}-w^{F}\right)\left(1-\tau^{H} B 1-\tau^{F} B 2\right) \\
& -A \cdot \frac{L^{H}}{\left(L^{H}+L^{H F}\right)^{2}}\left(\tau^{F} \cdot s f L-\tau^{H} \cdot s h L\right) \\
\Rightarrow & \frac{d Y^{H F}}{d L^{H F}}=w^{F}+\frac{1}{1-\tau^{H} B 1-\tau^{F} B 2} \cdot A \cdot \frac{L^{H}}{\left(L^{H}+L^{H F}\right)^{2}}\left(\tau^{F} \cdot s f L-\tau^{H} \cdot s h L\right)
\end{aligned}
$$




$$
\begin{aligned}
& \left(\frac{d Y^{F F}}{d L^{F F}}-w^{F}\right)\left(1-\tau^{F} D 1-\tau^{H} D 2\right) \\
& -C \cdot \frac{L^{F H}}{\left(L^{F F}+L^{F H}\right)^{2}}\left(\tau^{F} \cdot s f L-\tau^{H} \cdot s h L\right) \\
\Rightarrow & \frac{d Y^{F F}}{d L^{F F}}=w^{F}+\frac{1}{1-\tau^{F} D 1-\tau^{H} D 2} \cdot C \cdot \frac{L^{F H}}{\left(L^{F F}+L^{F H}\right)^{2}}\left(\tau^{F} \cdot s f L-\tau^{H} \cdot s h L\right) \\
& \left(\frac{d Y^{F H}}{d L^{F H}}-w\right)\left(1-\tau^{F} D 1-\tau^{H} D 2\right) \\
& -C \cdot \frac{L^{F F}}{\left(L^{F F}+L^{F H}\right)^{2}}\left(\tau^{H} \cdot \operatorname{sh} L-\tau^{F} \cdot s f L\right) \\
\Rightarrow & \frac{d Y^{F H}}{d L^{F H}}=w+\frac{1}{1-\tau^{F} D 1-\tau^{H} D 2} \cdot C \cdot \frac{L^{F F}}{\left(L^{F F}+L^{F H}\right)^{2}}\left(\tau^{H} \cdot \operatorname{sh} L-\tau^{F} \cdot s f L\right)
\end{aligned}
$$

Equations (3.31) and (3.33) show the optimality conditions for labour employed by the home based MNC at home and abroad. It is striking that not only the domestic and foreign wage rates but also the profit taxes and the weighting share of labour in the above formulae as well as the differences $\tau^{H} \cdot \operatorname{sh} L-\tau^{F} \cdot \operatorname{sf} L$ and $\tau^{F} \cdot \operatorname{sf} L-\tau^{H} \cdot \operatorname{sh} L$ affect the decision of how much labour to employ domestically and abroad. Assuming for instance an equal weight for payroll in the two formulae such that $s h L=s f L$, if the foreign wage rate $w^{F}$ is lower than the domestic wage rate $w$ and the domestic corporate tax is larger than the foreign one such that $\tau^{F}-\tau^{H}<0$, then the marginal product of labour employed in the foreign economy will be lower than in the domestic economy. However, even when the foreign wage rate is lower, if the foreign corporate tax is high enough compared to the domestic one, this effect might mitigate the effect of the lower foreign wage such that in the end the marginal product of labour abroad will be larger. More generally, it will be the difference between the foreign source tax multiplied with the share of payroll in the apportionment formula and the domestic profit tax multiplied with the domestic share of labour i.e. $\tau^{F} \cdot s f L-\tau^{H} \cdot s h L$ which will influence the different marginal products of labour in the two countries.

Looking now at the employment decision of MNCs vs. domestic corporations, one can see that given a unique domestic wage rate which both types of firms have tp pay to their employees, the marginal product of labour will differ between domestic corporations and 
home based MNCs (see eq. (2.20a), (2.21b) and (3.31), (3.34)). As long as the difference between the domestic and foreign profit tax is positive ${ }^{7} \tau^{H}-\tau^{F}>0$, the marginal product of labour under FA so accordingly the marginal product of labour which applies to MNCs will be higher than that one applying to domestic corporations (since these ones still stick to SA). Given a higher domestic corporate tax compared to the foreign one, the marginal product of labour of home and foreign based MNCs which invest domestically has to rise compared to the marginal product of labour of domestic corporations. ${ }^{8} \mathrm{~A}$ similar argument applies to foreign corporations and foreign and home based MNCs for their activities in the foreign economy.

Turning now to the investment decisions of home and foreign based MNCs, introducing FA changes the optimality conditions eq.(2.20) to ${ }^{9}$

$$
\begin{array}{lll}
\text { (a) } I^{H H}: & \eta_{t+1}^{H H} / R_{t+1}^{m}=J_{I}^{H H}+1 \\
\text { (b) } I^{H F}: & \eta_{t+1}^{H F} / R_{t+1}^{m}=J_{I}^{H F}+1
\end{array}
$$

and envelope conditions in the following way

$$
\begin{aligned}
\eta_{t}^{H H}= & \left(1-\tau^{H} B 1-\tau^{F} B 2\right)\left(Y_{K}^{H H}-J_{K}^{H H}\right) \\
& -A \frac{K^{H F}}{\left(K^{H H}+K^{H F}\right)^{2}}\left(\tau^{H} \cdot s h K-\tau^{F} \cdot s f K\right)+(1-\delta) \eta_{t+1}^{H H} / R_{t+1}^{m} \\
\eta_{t}^{H F}= & \left(1-\tau^{H} B 1-\tau^{F} B 2\right)\left(Y_{K}^{H F}-J_{K}^{H F}\right) \\
& -A \frac{K^{H}}{\left(K^{H H}+K^{H F}\right)^{2}}\left(\tau^{H} \cdot \operatorname{sh} K-\tau^{F} \cdot s f K\right)+(1-\delta) \eta_{t+1}^{H F} / R_{t+1}^{m}
\end{aligned}
$$

Assuming SS such that $J_{I}^{H H}=J_{I}^{H F}=J_{K}^{H H}=J_{K}^{H F}=0$ we can derive from the above equations the marginal product of capital for home based MNCs which invest domestically and abroad as

\footnotetext{
${ }^{7}$ Assuming once again equal shares for the payroll factor in the formulae of both countries so $s h L=s f L$

${ }^{8}$ This difference in the two different productivities can also be explained/achieved by the third factor which enters the production function of MNCs, namels the country specific fixed factor $E^{H}$.

${ }^{9} \mathrm{We}$ assume for simplicity no special investment allowances apply such that $\mathrm{e}=0$. The optimality and envelope conditions for foreign based MNCs are not presented here since they follow the same procedure.
} 


$$
\begin{aligned}
\text { (a) } \frac{d Y^{H H}}{d K^{H H}}= & \frac{1}{\left(1-\tau^{H} B 1-\tau^{F} B 2\right)}\left[\left(\delta+r^{m}\right)\right. \\
& \left.+A \cdot \frac{K^{H F}}{\left(K^{H H}+K^{H F}\right)^{2}}\left(\tau^{H} \cdot s h K-\tau^{F} \cdot s f K\right)\right] \\
\text { (b) } \frac{d Y^{H F}}{d K^{H F}}= & \frac{1}{\left(1-\tau^{H} B 1-\tau^{F} B 2\right)}\left[\left(\delta+r^{m}\right)\right. \\
& \left.+A \cdot \frac{K^{H H}}{\left(K^{H H}+K^{H F}\right)^{2}}\left(\tau^{H} \cdot \operatorname{sh} K-\tau^{F} \cdot s f K\right)\right]
\end{aligned}
$$

Comparing eq. (??) with the marginal product of capital for purely domestic corporations $Y_{K}^{H}=\left(r^{m}+\delta\right) \frac{1}{1-\tau^{H}}{ }^{10}$ which can be derived from eq.(2.12), we can see that the incentives for investing in domestic corporations vis-à-vis home-based MNCs will differ since each of the two firm types will be subject to a different taxation system. For instance, if $\tau^{H} \cdot \operatorname{sh} K-\tau^{F} \cdot s f K<0$ and $1-\tau^{H} B 1-\tau^{F} B 2>1-\tau^{H}$, the marginal product of capital under FA will be lower than under SA. This situation is depicted in Figure 1 below.

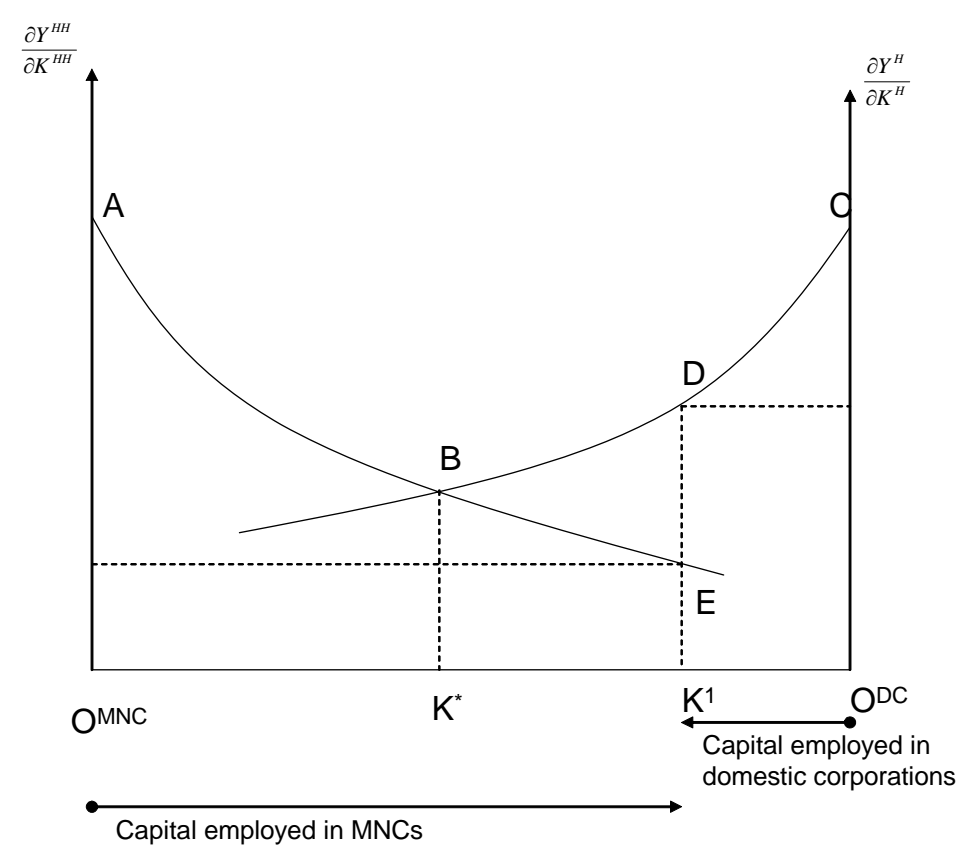

Fig. 1 Misallocation of capital within an economy under FA and SA

\footnotetext{
${ }^{10}$ Assuming $r^{m}=\frac{r^{V}}{1-t^{G}}$
} 
As Figure 1 shows, the optimal capital allocation within an economy $\mathrm{K}^{*}$ would be at the point where the marginal product of capital of home based MNCs and domestic corporations intersect. Here, domestic output is maximized and amounts to $\mathrm{ABK}^{*} \mathrm{O}^{M N C}$ plus $\mathrm{BCO}^{D C} K^{*}$. However, if both taxation systems apply at the same time and under the assumptions mentioned above, too much capital will be emplyed in the sector of MNCs and too little in domestic corporations such that we will have an overall output loss amounting to BDE.

Under a different tax costellation the opposite picture might occur such that there is too much capital employed by domestic corporations compared to MNCs. Nevertheless, the message is clear. Applying two different taxation systems at the same time will distort the allocation of capital within an economy resulting in a output loss. ${ }^{11}$

However, if we also consider the incentives of foreign based MNCs to invest domestically, if the domestic corporate tax multiplied with the share of capital in the domestic formula is lower than the foreign corporate tax multiplied with the share of capital in the foreign formula i.e. $\tau^{H} \cdot \operatorname{sh} K-\tau^{F} \cdot \operatorname{sf} K<0$, and if in addition $\tau^{F} D 1+\tau^{H} D 2>\tau^{H}$, a situation might arise in which the marginal product of capital under FA for foreign based MNCs is higher than the one for domestic corporations. (see eq.(??))

Regarding the investment incentives of foreign based MNCs, introducing FA now implies the following marginal product of capital

$$
\begin{aligned}
\text { (a) } \frac{d Y^{F F}}{d K^{F F}}= & \frac{1}{\left(1-\tau^{F} D 1-\tau^{H} D 2\right)}\left[\left(\delta+r^{m}\right)\right. \\
& \left.+C \cdot \frac{K^{F H}}{\left(K^{F H}+K^{F F}\right)^{2}}\left(\tau^{F} \cdot s f K-\tau^{H} \cdot s h K\right)\right] \\
\text { (b) } \frac{d Y^{F H}}{d K^{F H}}= & \frac{1}{\left(1-\tau^{F} D 1-\tau^{H} D 2\right)}\left[\left(\delta+r^{m}\right)\right. \\
& \left.+C \cdot \frac{K^{F F}}{\left(K^{F H}+K^{F F}\right)^{2}}\left(\tau^{F} \cdot s f K-\tau^{H} \cdot s h K\right)\right]
\end{aligned}
$$

Once again comparing eq. (??a), (??b) and $Y_{K}^{F}=\left(r^{m}+\delta\right) \frac{1}{1-\tau^{F}}$ which represent the investment incentives applying to purely foreign corporations, we can see that, in general,

\footnotetext{
${ }^{11}$ The investment incentives under SA and FA will equalize only in case $\tau^{H} \cdot \operatorname{sh} K-\tau^{F} \cdot s f K=0$ and $\tau^{H} B 1-\tau^{F} B 2=\tau^{H}$.
} 
the two different taxation systems will drive a wedge between the marginal product of capital for the two firm types operating abroad, resulting in a misallocation of capital in the foreign economy as well.

The analysis of this system change within a dynamic framework is completed with the study of the transition path from the initial to the final steady state.

The dynamics of the transition under perfect foresight from the initial SS under SA to the final SS under FA depends on the particular tax constellation. Since we have a 'two point boundary value problem', the system starts at a predetermined capital stock given for instance for the domestic economy by $K_{t}^{H H}=K_{0}^{H H}$. The future equilibrium of the system is reflected by the shadow price of capital $\eta_{t}^{H H}$. The transition between the initial and the final steady state must satisfy the following difference equation system for the predetermined and forward looking variables where optimal investment is solved from eq.(2.20c))

$$
\begin{aligned}
G K_{t+1}^{H H} & =I_{t}^{H H}+(1-\delta) K_{t}^{H H}, I_{t}^{H H}=I\left(\eta_{t+1}^{H H}, K_{t}^{H H}\right) \\
\eta_{t}^{H H} & =\left(1-\tau^{H}\right)\left(Y_{K}^{H H}-J_{K}^{H H}\right)+(1-\delta) \eta_{t+1}^{H H} / R_{t+1}^{m}
\end{aligned}
$$

Figure 2 depicts how the two variables, capital $K^{H H}$ and its value $\eta^{H H}$ behave to satisfy eq.(??) at every point in time given their initial values. To characterize the transition path we show how the shadow price and the capital stock affect investment. Accordingly

$$
\begin{aligned}
\Delta K^{H H} & =K_{t+1}^{H H}-K_{t}^{H H}=\left[I\left(\eta_{t+1}^{H H}, K_{t}^{H H}\right)-(\delta+g) K_{t}^{H H}\right] / G \\
\Delta \eta^{H H} & =\eta_{t+1}^{H H}-\eta_{t}^{H H}=\eta_{t}^{H H} \frac{r_{t+1}^{m}+\delta}{1-\delta}-\frac{\left(1-\tau^{H}\right)\left(Y_{K}^{H H}-J_{K}^{H H}\right) R_{t+1}^{m}}{1-\delta}
\end{aligned}
$$

Suppose, for instance, that the starting point is B. Because $\eta^{H H}$ is larger than its equilibrium value, firms increase the capital stock. Accordingly $\Delta K^{H H}>0$. Since profits are low because $K^{H H}$ is high, $\eta^{H H}$ can also be high only in case it is expected to rise such that 
$\Delta \eta^{H H}>0$. Consequently, we will move in the diagram up and to the right. The quantity of capital in the economy is inherited from the past and only the market value of capital adjusts. Therefore, for a specific value of $K^{H H}$ we can compute a unique value for $\eta^{H H}$ that determines the saddle path $\eta^{H H}\left(K^{H H}\right)$. Along this path $K^{H H}$ and $\eta^{H H}$ converge to the unique equilibrium point A. This long-run equilibrium is characterized by $\eta^{H H}=1$, $Y_{K}^{H H}=\left(r^{m}+\delta\right) \frac{1}{1-\tau^{H}}$ and $I^{H H}=(\delta+g) K^{H H}$ (implying $\left.\Delta K^{H H}=0\right)$ and $\Delta \eta^{H H}=0$ such that given the interest rates and tax parameters, firms have no incentive to decrease or increase the capital stock (ROMER, 2001).

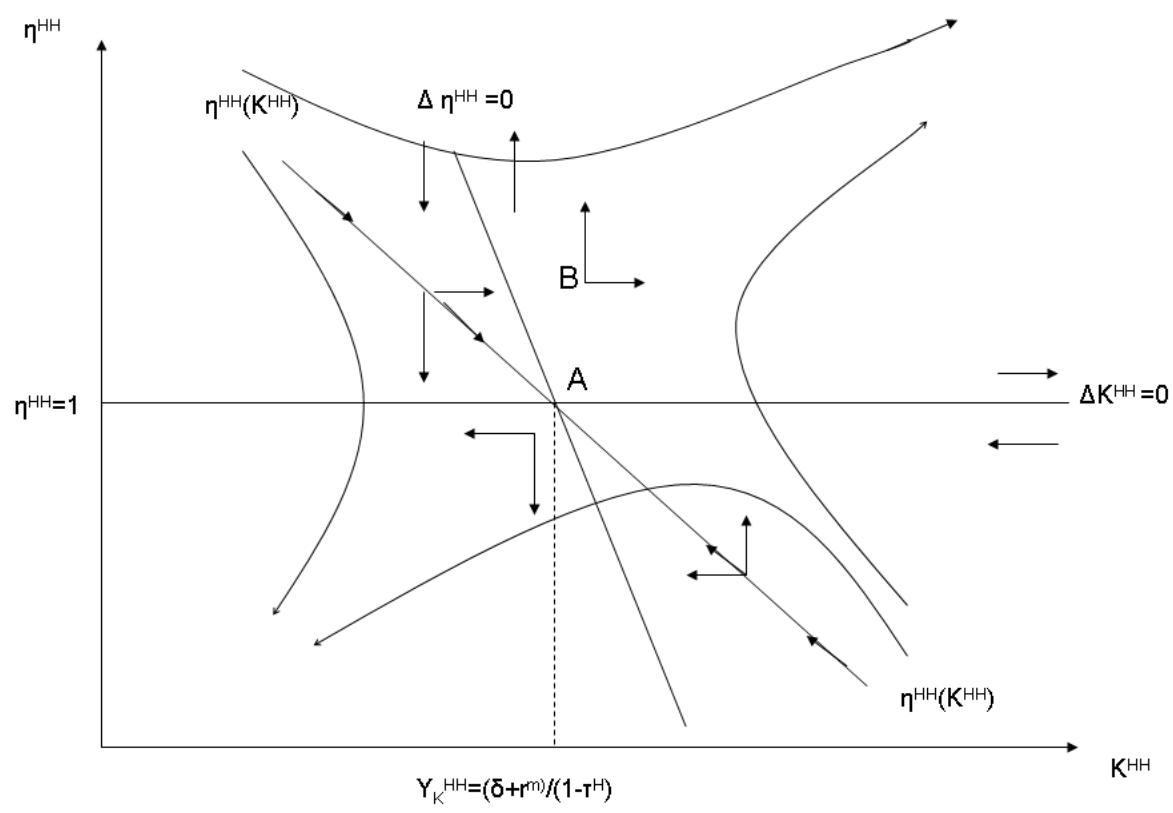

Fig. 2 Investment Dynamics under Perfect Foresight

The transition to FA changes the envelope condition and accordingly also the $\Delta \eta^{H H}$ locus (see eq.(??) below). It is not clear however whether more or less capital will be accumulated within the sector of home based MNCs.

$$
\begin{aligned}
\Delta \eta^{H H}= & \eta_{t+1}^{H H}-\eta_{t}^{H H}=\eta_{t}^{H H} \frac{r_{t+1}^{m}+\delta}{1-\delta}-\frac{R_{t+1}^{m}}{1-\delta}\left(1-\tau^{H} B 1-\tau^{F} B 2\right)\left(Y_{K}^{H H}-J_{K}^{H}(3) 42\right) \\
& +\frac{R_{t+1}^{m}}{1-\delta} A \frac{K^{H F}}{\left(K^{H H}+K^{H F}\right)^{2}}\left(\tau^{H} \cdot \operatorname{shK}-\tau^{F} \cdot s f K\right)
\end{aligned}
$$

If, for instance as assumed above $\tau^{H} \cdot s h K-\tau^{F} \cdot s f K<0$, then the locus of the 
$\Delta \eta^{H H}=0$ curve is shifted upwards (see Fig. 3). The economy is initially in the long-run equilibrium at point $E^{1} \cdot \eta^{H H}$ jumps to the point on the new saddle path for the given capital stock $\left(E^{2}\right) . K^{H H}$ and $\eta^{H H}$ then move down along the path to the new equilibrium point $E^{3}$. Thus, under these assumptions, the introduction of FA leads to an increase in the capital stock from $K^{H H}$ to $K^{H H^{\prime}}$

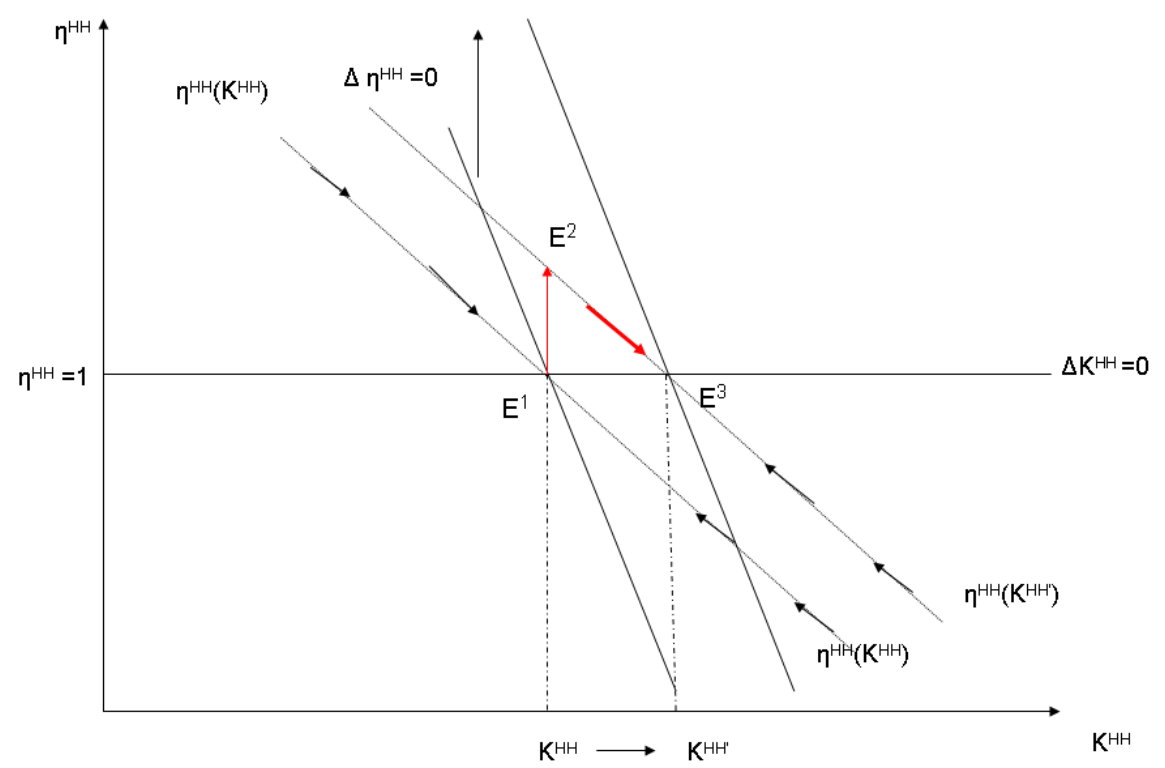

Fig. 3 The transition from Formula Apportionment to Separate Accounting

Nevertheless, this transition path is depicted for a specific tax constellation. Under different assumptions which lead to a higher marginal product of capital under FA than under SA, capital within the sector of domestic based MNCs might decumulate.

\section{Conclusion}

The aim of this paper was twofold. We first attempted to analyze the switch from SA to FA within a dynamic framework. The second main purpose was to shed light on how the co-existence of two different tax systems, each applying to a different firm type, affects the allocation of capital between MNCs and purely domestic corporations within an economy. Our findings show that the introduction of FA leads to a loss in domestic output since both the marginal product of labour and the investment incentives will differ for the two 
firm types. Thus the parallel existence of SA and FA creates a distortion in the allocation of labour and capital. Nevertheless, it is not clear whether MNCs or purely domestic or purely foreign corporations will benefit from this system change since the results depend on the particular tax constellations. Different scenarios lead either to an accumulation or a decumulation of capital in the sector of home based MNCs depending on the domestic and foreign corporate tax, the share of labour and capital in the domestic and foreign formula and the difference between the domestic tax rate multiplied with share of the respective factor in the domestic formula less the foreign tax rate multiplied with share of the respective factor in the foreign formula.

\section{Appendix - Functional Forms}

- Agency cost of transfer pricing (see also Riedel And Runkel 2007 and KeuschnigG (2003 and 2005):

$$
\begin{aligned}
& p^{Q} \geq 1: c\left(p^{Q}-1\right)=\frac{\left(p^{Q}-1\right)^{1+1 / \varepsilon^{Q}}}{1+1 / \varepsilon^{Q}}>0, \quad c^{\prime}=\left(p^{Q}-1\right)^{1 / \varepsilon^{Q}}>0, \\
& p^{Q}<1: c\left(p^{Q}-1\right)=\frac{\left(1-p^{Q}\right)^{1+1 / \varepsilon^{Q}}}{1+1 / \varepsilon^{Q}}>0, \quad c^{\prime}=-\left(1-p^{Q}\right)^{1 / \varepsilon^{Q}}<0 .
\end{aligned}
$$

- Production function home based multinational

$$
\begin{aligned}
Y^{H} & =Y\left[F\left(K^{H}, L^{H}\right), E^{H}\right]=\left[\left(K^{H}\right)^{\alpha}\left(L^{H}\right)^{1-\alpha}\right]^{\gamma}\left(E^{H}\right)^{1-\gamma}, \\
Y^{H F i} & =Y\left[F\left(K^{H F i}, L^{H F i}\right), Q^{H i}, E^{H F i}\right]=\left[\left(K^{H F i}\right)^{\alpha}\left(L^{H F i}\right)^{1-\alpha}\right]^{\gamma}\left(Q^{H}\right)^{\gamma^{Q}}\left(E^{H F i}\right)^{1-\gamma-\gamma^{Q}} .
\end{aligned}
$$

\section{References}

[1] Anand, B. and R. Sansing (2000), 'The Weighting Game: Formula Apportionment as an Instrument of Public Policy', National Tax Journal 53, 183-199.

[2] Büttner, T. and M. Ruf (2007), 'Tax Incentives and the Location of FDI: Evidence from a Panel of German Multinationals', International Tax and Public Finance, forthcoming 
[3] Eggert, W. and G. Schjelderup (2003), 'Symmetric Tax Competition under Formula Apportionment', Journal of Public Economic Theory 5, 439-446.

[4] Eggert, W. and G. Schjelderup (2005), 'Corporate Tax Systems and Cross Country Profit Shifting: Formula Apportionment versus Separate Accounting, mimeo.

[5] European Commission (2001), 'Towards an Internal Market Without Tax Obstacles: A Strategy for Providing Companies with a Consolidated Corporate Tax Base for Their EU WideActivities, COM 2001, 582 final.

[6] Fuest, C., T. Hemmelgarn and F. Ramb (2006), How Would the Introduction of Formula Apportionment in the EU Affect the Distribution and Size of the Corporate Tax Base? An Analysis Based on Data of German Multinationals, International Tax and Public Finance, forthcoming

[7] Gerard, M. and J.M.Weiner (2003), 'Cross-Border Loss Offset and Formulary Apprtionment: How Do They Affect Multijurisdictional Firm Investment Spending and Interjurisdictional Tax Competitio?', CESifo Working Paper N0. 1004, University of Munich

[8] Goolsbee, A. and E.Maydew (2000), Coveting the neighbor's manufacturing: the dilemma of state income apportionment, Journal of Public Economics 75, 125-143.

[9] Gordon, R.H. and J.D. Wilson (1986), 'An Examination of Multijurisdictional Corporate Income Taxation under Formula Apportionment', Econometrica 54, 1357-1373.

[10] Hines, J.R. Jr. (1999), 'Lessons from Behavioral Responses to International Taxation', National Tax Journal 52, 305-322.

[11] Keuschnigg, C. (2003), Taxation and Foreign Direct Investment, model documentation, University of St.Gallen.

[12] Keuschnigg, C. (2005), IFF Tax Model Version III, model documentation, University of St. Gallen.

[13] Mintz, J. (1999), 'Globalization of the Corporation Income Tax: The Role of Allocation', Finanzarchiv 56, 389-423.

[14] Mintz, J. and M. Smart (2004), 'Income Shifting, Investment and Tax Competition:Theory and Evidence from Provintial Taxation in Canada', Journal of Public Economics 88, 1149-1168

[15] McLure, C.E (1980), 'The State Corporate Income Tax : Lambs in Wolves' Clothing', in: Aaron, A.J. and M.J. Boskin (Eds.), The Economics of Taxation, Washington D.C: The Brookings Institution, 327-336.

[16] Nielsen, S.B. , Raimondos-Moeller, P. and G. Schjelderup (2003), 'Formula Apportionment and Transfer Pricing under Oligopolistic Competition', Journal of Public Economic Theory 5, 419-437 
[17] Nielsen, S.B. , Raimondos-Moeller, P. and G. Schjelderup (2004), 'Company Taxation and Tax Spillovers: Separate Accounting versus Formula Apportionment', mimeo.

[18] Riedel, N. and M. Runkel (2007), Company Tax Reform with a Water's Edge, Journal of Public Economics, forthcoming

[19] Romer, D. (2001), Advanced Macroeconomics, New York: Mc Graw Hill.

[20] Sørensen,P.B. (2004), 'Company Tax Reform in the European Union', International Tax and Public Finance 11, 91-115. 


\section{CESifo Working Paper Series}

for full list see www.cesifo-group.org/wp

(address: Poschingerstr. 5, 81679 Munich, Germany, office@cesifo.de)

2060 Tigran Poghosyan and Jakob de Haan, Interest Rate Linkages in EMU Countries: A Rolling Threshold Vector Error-Correction Approach, July 2007

2061 Robert Dur and Klaas Staal, Local Public Good Provision, Municipal Consolidation, and National Transfers, July 2007

2062 Helge Berger and Anika Holler, What Determines Fiscal Policy? Evidence from German States, July 2007

2063 Ernesto Reuben and Arno Riedl, Public Goods Provision and Sanctioning in Privileged Groups, July 2007

2064 Jan Hanousek, Dana Hajkova and Randall K. Filer, A Rise by Any Other Name? Sensitivity of Growth Regressions to Data Source, July 2007

2065 Yin-Wong Cheung and Xing Wang Qian, Hoarding of International Reserves: Mrs Machlup’s Wardrobe and the Joneses, July 2007

2066 Sheilagh Ogilvie, 'Whatever Is, Is Right'?, Economic Institutions in Pre-Industrial Europe (Tawney Lecture 2006), August 2007

2067 Floriana Cerniglia and Laura Pagani, The European Union and the Member States: Which Level of Government Should Do what? An Empirical Analysis of Europeans' Preferences, August 2007

2068 Alessandro Balestrino and Cinzia Ciardi, Social Norms, Cognitive Dissonance and the Timing of Marriage, August 2007

2069 Massimo Bordignon, Exit and Voice. Yardstick versus Fiscal Competition across Governments, August 2007

2070 Emily Blanchard and Gerald Willmann, Political Stasis or Protectionist Rut? Policy Mechanisms for Trade Reform in a Democracy, August 2007

2071 Maarten Bosker and Harry Garretsen, Trade Costs, Market Access and Economic Geography: Why the Empirical Specification of Trade Costs Matters, August 2007

2072 Marco Runkel and Guttorm Schjelderup, The Choice of Apportionment Factors under Formula Apportionment, August 2007

2073 Jay Pil Choi, Tying in Two-Sided Markets with Multi-Homing, August 2007

2074 Marcella Nicolini, Institutions and Offshoring Decision, August 2007 
2075 Rainer Niemann, The Impact of Tax Uncertainty on Irreversible Investment, August 2007

2076 Nikitas Konstantinidis, Gradualism and Uncertainty in International Union Formation, August 2007

2077 Maria Bas and Ivan Ledezma, Market Access and the Evolution of within Plant Productivity in Chile, August 2007

2078 Friedrich Breyer and Stefan Hupfeld, On the Fairness of Early Retirement Provisions, August 2007

2079 Scott Alan Carson, Black and White Labor Market Outcomes in the $19^{\text {th }}$ Century American South, August 2007

2080 Christian Bauer, Paul De Grauwe and Stefan Reitz, Exchange Rates Dynamics in a Target Zone - A Heterogeneous Expectations Approach, August 2007

2081 Ana Rute Cardoso, Miguel Portela, Carla Sá and Fernando Alexandre, Demand for Higher Education Programs: The Impact of the Bologna Process, August 2007

2082 Christian Hopp and Axel Dreher, Do Differences in Institutional and Legal Environments Explain Cross-Country Variations in IPO Underpricing?, August 2007

2083 Hans-Werner Sinn, Pareto Optimality in the Extraction of Fossil Fuels and the Greenhouse Effect: A Note, August 2007

2084 Robert Fenge, Maximilian von Ehrlich and Matthias Wrede, Fiscal Competition, Convergence and Agglomeration, August 2007

2085 Volker Nitsch, Die Another Day: Duration in German Import Trade, August 2007

2086 Kam Ki Tang and Jie Zhang, Morbidity, Mortality, Health Expenditures and Annuitization, August 2007

2087 Hans-Werner Sinn, Public Policies against Global Warming, August 2007

2088 Arti Grover, International Outsourcing and the Supply Side Productivity Determinants, September 2007

2089 M. Alejandra Cattaneo and Stefan C. Wolter, Are the Elderly a Threat to Educational Expenditures?, September 2007

2090 Ted Bergstrom, Rod Garratt and Damien Sheehan-Connor, One Chance in a Million: Altruism and the Bone Marrow Registry, September 2007

2091 Geraldo Cerqueiro, Hans Degryse and Steven Ongena, Rules versus Discretion in Loan Rate Setting, September 2007 
2092 Henrik Jacobsen Kleven, Claus Thustrup Kreiner and Emmanuel Saez, The Optimal Income Taxation of Couples as a Multi-Dimensional Screening Problem, September 2007

2093 Michael Rauber and Heinrich W. Ursprung, Life Cycle and Cohort Productivity in Economic Research: The Case of Germany, September 2007

2094 David B. Audretsch, Oliver Falck and Stephan Heblich, It's All in Marshall: The Impact of External Economies on Regional Dynamics, September 2007

2095 Michael Binder and Christian J. Offermanns, International Investment Positions and Exchange Rate Dynamics: A Dynamic Panel Analysis, September 2007

2096 Louis N. Christofides and Amy Chen Peng, Real Wage Chronologies, September 2007

2097 Martin Kolmar and Andreas Wagener, Tax Competition with Formula Apportionment: The Interaction between Tax Base and Sharing Mechanism, September 2007

2098 Daniela Treutlein, What actually Happens to EU Directives in the Member States? - A Cross-Country Cross-Sector View on National Transposition Instruments, September 2007

2099 Emmanuel C. Mamatzakis, An Analysis of the Impact of Public Infrastructure on Productivity Performance of Mexican Industry, September 2007

2100 Gunther Schnabl and Andreas Hoffmann, Monetary Policy, Vagabonding Liquidity and Bursting Bubbles in New and Emerging Markets - An Overinvestment View, September 2007

2101 Panu Poutvaara, The Expansion of Higher Education and Time-Consistent Taxation, September 2007

2102 Marko Koethenbuerger and Ben Lockwood, Does Tax Competition Really Promote Growth?, September 2007

2103 M. Hashem Pesaran and Elisa Tosetti, Large Panels with Common Factors and Spatial Correlations, September 2007

2104 Laszlo Goerke and Marco Runkel, Tax Evasion and Competition, September 2007

2105 Scott Alan Carson, Slave Prices, Geography and Insolation in $19^{\text {th }}$ Century AfricanAmerican Stature, September 2007

2106 Wolfram F. Richter, Efficient Tax Policy Ranks Education Higher than Saving, October 2007

2107 Jarko Fidrmuc and Roman Horváth, Volatility of Exchange Rates in Selected New EU Members: Evidence from Daily Data, October 2007 
2108 Torben M. Andersen and Michael Svarer, Flexicurity - Labour Market Performance in Denmark, October 2007

2109 Jonathan P. Thomas and Tim Worrall, Limited Commitment Models of the Labor Market, October 2007

2110 Carlos Pestana Barros, Guglielmo Maria Caporale and Luis A. Gil-Alana, Identification of Segments of European Banks with a Latent Class Frontier Model, October 2007

2111 Felicitas Nowak-Lehmann D., Sebastian Vollmer and Immaculada Martínez-Zarzoso, Competitiveness - A Comparison of China and Mexico, October 2007

2112 Mark Mink, Jan P.A.M. Jacobs and Jakob de Haan, Measuring Synchronicity and Comovement of Business Cycles with an Application to the Euro Area, October 2007

2113 Ossip Hühnerbein and Tobias Seidel, Intra-regional Tax Competition and Economic Geography, October 2007

2114 Christian Keuschnigg, Exports, Foreign Direct Investment and the Costs of Corporate Taxation, October 2007

2115 Werner Bönte, Oliver Falck and Stephan Heblich, Demography and Innovative Entrepreneurship, October 2007

2116 Katrin Assenmacher-Wesche and M. Hashem Pesaran, Assessing Forecast Uncertainties in a VECX Model for Switzerland: An Exercise in Forecast Combination across Models and Observation Windows, October 2007

2117 Ben Lockwood, Voting, Lobbying, and the Decentralization Theorem, October 2007

2118 Andrea Ichino, Guido Schwerdt, Rudolf Winter-Ebmer and Josef Zweimüller, Too Old to Work, too Young to Retire?, October 2007

2119 Wolfgang Eggert, Tim Krieger and Volker Meier, Education, Unemployment and Migration, October 2007

2120 Stefan Napel and Mika Widgrén, The European Commission - Appointment, Preferences, and Institutional Relations, October 2007

2121 Bertil Holmlund and Martin Söderström, Estimating Income Responses to Tax Changes: A Dynamic Panel Data Approach, October 2007

2122 Doina Maria Radulescu, From Separate Accounting to Formula Apportionment: Analysis in a Dynamic Framework, October 2007 